\title{
The Regulation of Adipose Tissue and Muscle Lipoprotein Lipase in Runners by Detraining
}

Rosa B. Simsolo, John M. Ong, and Philip A. Kern

Department of Medicine, Division of Endocrinology, Cedars-Sinai Medical Center, Los Angeles, California 90048

\begin{abstract}
To study the mechanism of lipoprotein lipase (LPL) regulation by exercise, we recruited 16 healthy athletes to undergo a 2-wk period of detraining. Fasting fat and muscle biopsies were performed both before and after the detraining period. In muscle, detraining resulted in a decrease in LPL activity in both the heparin-releasable (HR) $(-45 \%, P<0.05)$ and cellular (extractable $[\mathrm{EXT}])(-75 \%, P<0.005)$ fractions, with no signifcant changes in LPL immunoreactive mass and mRNA levels. However, several subjects demonstrated parallel decreases in LPL mass and mRNA levels with detraining, suggesting that there is some degree of heterogeneity in response. In adipose tissue, detraining had the opposite effects on LPL activity. In the HR fraction, detraining resulted in an $86 \%$ increase $(P$ $<0.005)$ in LPL activity, which was paralleled by a $100 \%$ ( $P$ $=0.02$ ) increase in HR mass. However, there was no significant change in EXT LPL activity or EXT LPL mass. There were no changes in adipose LPL synthetic rate or LPL mRNA levels with detraining. The ratio of adipose tissue / muscle LPL, which may be an important indicator of the tendency for storage of circulating lipids in adipose tissue, increased significantly after detraining. The adipose/muscle LPL ratio was $0.51 \pm 0.17$ in the exercising runners, and $4.45 \pm 2.46$ in the same runners after detraining $(P<0.05)$. Thus, detraining of athletes resulted in a decrease in muscle LPL that occurred through posttranslational mechanisms, whereas adipose tissue LPL increased, also due to posttranslational changes. This decrease in muscle LPL, coupled with an increase in adipose LPL, yielded a condition favoring adipose tissue storage. (J. Clin. Invest. 1993. 92:2124-2130.) Key words: exercise • lipid metabolism • obesity • posttranslational processing
\end{abstract}

This work was supported by a Grant-in-Aid from the American Heart Association, a Career Development Award from the Juvenile Diabetes Foundation, and National Institutes of Health grant DK-39176. This work was done during the tenure of an Established Investigatorship from the American Heart Association.

Address correspondence to Dr. Philip A. Kern, Division of Endocrinology, Becker 131, Cedars-Sinai Medical Center, 8700 Beverly Boulevard, Los Angeles, CA 90048.

Received for publication 12 February 1993 and in revised form 26 May 1993.

J. Clin. Invest.

(c) The American Society for Clinical Investigation, Inc.

$0021-9738 / 93 / 11 / 2124 / 07 \quad \$ 2.00$

Volume 92, November 1993, 2124-2130

\section{Introduction}

Triglyceride-derived FFA are taken up by tissues through the action of lipoprotein lipase (LPL) ${ }^{1}(1)$, which is found predominantly in adipose tissue and muscle. In human adipose tissue, little FFA is synthesized from glucose, and therefore LPL is an important enzyme for lipid storage (2). In contrast, muscle uses FFA for oxidation (3). The LPL found in both adipose tissue and muscle contributes to the clearance of circulating triglyceride-rich lipoproteins.

Previous studies have examined the effects of exercise on LPL activity, using a number of different exercise regimens (reviewed in reference 4). Studies of endurance training in human subjects showed significant increases in LPL activity, both in skeletal muscle and adipose tissue, as well as in postheparin plasma. Weight loss also yields increases in adipose LPL (5), however, and many studies of exercise did not control for weight loss during the exercise regimen. Kiens et al. (6) studied six healthy men in which LPL activity was measured in the knee extensors at rest and after 8 wk of training of one leg, while the other leg was not exercised and served as a control. They found a $70 \%$ increase in LPL activity in the trained leg compared with the nontrained one.

A number of previous studies have examined the mechanism of LPL regulation, and have discovered that LPL may be regulated at multiple different cellular sites (7). This study was designed to examine the mechanism of regulation of LPL by exercise in adipose tissue and muscle. As described below, short-term changes in exercise altered LPL activity in both tissues through posttranslational changes.

\section{Methods}

Recruitment of study subjects. 16 subjects ( 10 men and 6 women; age, $37 \pm 2 \mathrm{yr}$ ) were recruited for this study, and their characteristics are shown in Table I. All subjects were in good health, were taking no medications, and were running $\geq 32 \mathrm{~km} / \mathrm{wk}$, or performing an equivalent amount of aerobic exercise (one subject bicycled $\sim 600 \mathrm{~km} /$ week). 6 of the 16 subjects ran a marathon within 1 mo preceding the study. To participate in the study, the subjects had to agree to detrain for $2 \mathrm{wk}$, and gave informed consent to the procedures. Detraining entailed no aerobic exercise, but just activities of daily living. Compliance with these instructions was judged to be excellent. This protocol was approved by the Internal Review Board of Cedars-Sinai Medical Center, and subjects gave informed consent to the procedures.

$2 \mathrm{~d}$ before the biopsies, all subjects were placed on an isocaloric diet consisting of $50 \%$ carbohydrate, $20 \%$ protein, and $30 \%$ fat, which was in all cases very similar to subjects' standard diet. Subjects presented to

1. Abbreviations used in this paper: EXT, extractable lipoprotein lipase; HR, heparin-releasable lipoprotein lipase; LPL, lipoprotein lipase. 
the clinic after a 12-h fast. A 3-d diet record was kept before each study to account for compliance. The fat biopsies were performed under local anesthesia, using a 2-3-cm incision in the lower abdominal wall to obtain 3-4 $\mathrm{g}$ of fat, as described previously (8). The muscle needle biopsy was performed under local anesthesia in the thigh and removed 200-300 mg of muscle from the vastus lateralis. A portion of the excised tissues was placed into iced PBS and processed immediately for LPL activity, immunoreactive mass, and synthetic rate, as described below. A second portion of the tissues was immediately frozen in liquid nitrogen and stored at $-70^{\circ} \mathrm{C}$ for subsequent RNA isolation. In addition, blood samples were obtained for lipids, glucose, and insulin. In a subgroup of the study subjects, body composition was also measured by bioelectrical impedance $(9,10)$, which would be expected to detect a 3\% change in lean body mass (9). After 10-14 d of detraining the subjects were placed again on the same standardized diet and the same procedure were repeated. All subjects tolerated the procedure well.

Measurement of LPL activity. LPL catalytic activity was measured in two fractions, as described previously: the fraction released by heparin (HR), as well as in the fraction remaining after heparin release that was found in cell extracts (EXT) (11). In brief, adipose tissue and muscle were minced and incubated in PBS containing $13 \mu \mathrm{g} / \mathrm{ml}$ heparin (Fisher Scientific Co., Pittsburgh, PA) for $30 \mathrm{~min}$ at $37^{\circ} \mathrm{C}$. An aliquot of this buffer was then assayed as described below. The cells were then washed and the EXT fraction was prepared by homogenizing the cells in buffer containing deoxycholate and heparin, as described previously (11). LPL activity was then measured in the supernatant after centrifugation at $3,000 \mathrm{~g}$.

LPL activity was determined as described previously (12) using a $\left[{ }^{3} \mathrm{H}\right]$ triolein-containing substrate emulsified with lecithin, and containing normal human serum as a source of apo CII. $100 \mu$ l of the HR sample and $10 \mu \mathrm{l}$ of the EXT sample (to avoid inhibition by the detergents) were incubated with $100 \mu \mathrm{l}$ of the substrate for $45 \mathrm{~min}$ at $37^{\circ} \mathrm{C}$. The reaction was stopped by the addition of a mixture of chloroformmethanol-heptane (13), and liberated $\left[{ }^{3} \mathrm{H}\right]$ FFA were separated and quantitated by liquid scintillation. Activity was expressed as nEq FFA released $/ \mathrm{min}$ per $10^{6}$ cells for adipose tissue, and nanoequivalents (nEq) FFA released/min per gram in muscle.
LPL immunoreactive mass. The measurement of LPL immunoreactive mass by ELISA has been described previously $(11,14)$. In brief, samples for LPL immunoreactive mass were prepared as described above for LPL activity, except for the presence of protease inhibitors ( 1 mM PMSF, $1 \mathrm{mM}$ benzamidine, and $1 \mathrm{mM}$ EGTA) in all the buffers. The sandwich-type ELISA uses affinity-purified chicken anti-bovine LPL antibodies (14) as a capture antibody. After addition of sample or bovine LPL standard, LPL is quantitated by the addition of biotinylated affinity-purified anti-LPL antibody, followed by streptavidin-peroxidase. The concentration of LPL in the samples was then calculated using the standard curve for bovine LPL, and expressed as ng/ $10^{6}$ cells or $\mathrm{ng} / \mathrm{g}$ for adipose and muscle, respectively.

$\left[{ }^{35} \mathrm{~S}\right]$ Methionine labeling and immunoprecipitation. Adipose tissue was minced, washed three times with methionine-free medium 199 (Irvine Scientific, Santa Ana, CA), and incubated in the same medium for $1 \mathrm{~h}$ at $37^{\circ} \mathrm{C}$ in preparation for radiolabeling. The tissue was then labeled with $50 \mu \mathrm{Ci}$ of $\left[{ }^{35} \mathrm{~S}\right.$ ] methionine for $30 \mathrm{~min}$. Lysis buffer was then added to give a final lysate concentration of $0.02 \mathrm{M}$ sodium phosphate (ph 7.5), $0.2 \mathrm{mM} \mathrm{NaCl}, 2 \%$ (vol/vol) Triton X-100, 1\% (wt/ vol) sodium deoxycholate, $0.2 \%$ (wt/vol) SDS, $5 \mathrm{mM}$ EDTA, and 1 mM PMSF. The samples were immunoprecipitated, as described previously $(15,16)$, and analyzed using a $10 \%$ SDS-polyacrylamide gel. After autoradiography, the intensity of the bands was quantitated by laser densitometry using a soft laser scanning densitometer (SLR-2D/ 1D; Zeineh, Fullerton, CA). To control for minor differences in labeling conditions between biopsies, as well as for isotopic decay of the ${ }^{35} \mathrm{~S}$, an aliquot of adipose tissue extract was precipitated with TCA at the time of immunoprecipitation and SDS-PAGE. The immunoprecipitates were then loaded onto the gel in proportion to the total TCA-precipitable counts.

RNA extraction and Northern analysis. RNA was extracted using the method of Chomczynski and Sacchi (17), as described previously (16). Similar amounts of total RNA (confirmed by ethidium bromide staining) were resolved on a $2.2 \mathrm{M}$ formaldehyde- $1 \%$ agarose gel, transferred to nylon membrane (Hybond-N; Amersham Corp., Arlington Heights, IL), and blotted with the ${ }^{32}$ P-labeled (18) cDNA probes for human LPL (19), gamma-actin (20), as described previously (8). The

Table I. Clinical Characteristics of the Subjects

\begin{tabular}{|c|c|c|c|c|c|c|c|c|c|}
\hline Subject & Sex & Age & $\begin{array}{l}\text { Distance } \\
\text { run/wk }\end{array}$ & BMI & HDL & Cholesterol & LDLC & TG & Insulin \\
\hline & & $y r$ & $\mathrm{~km}$ & $\mathrm{~kg} / \mathrm{m}^{2}$ & $\mathrm{mg} / 100 \mathrm{ml}$ & $\mathrm{mg} / 100 \mathrm{ml}$ & $\mathrm{mg} / 100 \mathrm{ml}$ & $\mathrm{mg} / 100 \mathrm{ml}$ & $u U / m l$ \\
\hline 1 & $\mathbf{M}$ & 32 & 32 & 22.4 & 58 & 158 & 85 & 75 & 9.3 \\
\hline 2 & $\mathrm{~F}$ & 45 & 40 & 20.2 & 86 & 203 & 101 & 78 & 9.6 \\
\hline 3 & $\mathbf{M}$ & 39 & 48 & 23.1 & 71 & 163 & 85 & 36 & 8.9 \\
\hline 4 & $\mathrm{~F}$ & 29 & 40 & 22.3 & 71 & 193 & 114 & 41 & 14.0 \\
\hline 5 & $\mathbf{M}$ & 35 & 32 & 28.1 & 33 & 160 & 107 & 100 & 13.0 \\
\hline $6(\mathrm{~m})$ & $\mathbf{M}$ & 32 & 80 & 24.0 & 64 & 155 & 73 & 88 & 6.0 \\
\hline 7 & $\mathbf{M}$ & 54 & 56 & 23.2 & 44 & 235 & 167 & 122 & 17.0 \\
\hline 8 & $F$ & 25 & $-^{*}$ & 22.8 & 56 & 177 & 96 & 126 & 13.0 \\
\hline 9 & $\mathbf{M}$ & 25 & $-{ }^{\ddagger}$ & 22.3 & 44 & 131 & 73 & 70 & 11.0 \\
\hline $10(\mathrm{~m})$ & $\mathrm{F}$ & 41 & 88 & 22.3 & 63 & 165 & 95 & 37 & 8.5 \\
\hline $11(\mathrm{~m})$ & $\mathbf{M}$ & 33 & 96 & 22.9 & 59 & 144 & 68 & 85 & 9.4 \\
\hline $12(\mathrm{~m})$ & $\mathbf{M}$ & 38 & 40 & 23.0 & 48 & 157 & 90 & 97 & 7.8 \\
\hline $13(\mathrm{~m})$ & $\mathbf{M}$ & 47 & 40 & 24.5 & 60 & 185 & 112 & 67 & 9.9 \\
\hline 14 & $\mathrm{~F}$ & 48 & 45 & 25.9 & 63 & 223 & 144 & 81 & 13.0 \\
\hline 15 & $F$ & 39 & 57 & 21.8 & 62 & 186 & 101 & 117 & 19.0 \\
\hline $16(\mathrm{~m})$ & $\mathbf{M}$ & 40 & 60 & 23.9 & 51 & 103 & 44 & 41 & N/A \\
\hline
\end{tabular}

m, marathon runners; BMI, body mass index; LDLc, low density lipoprotein cholesterol; TG, triglyceride.

* $3 \mathrm{~h} / \mathrm{d}$ of aerobic exercise, $6 \mathrm{~d} / \mathrm{wk}$.

${ }^{\ddagger}$ Cyclist, $.80 \mathrm{~km} / \mathrm{d}, 5 \mathrm{~d} / \mathrm{wk}$. 
images from the Northern blots were quantitated by densitometry using a soft laser scanning densitometer (SLR-2D/1D; Zeineh). Because the ratio of actin mRNA to total cellular RNA usually remains constant, actin cDNA hybridization permitted accurate comparisons between samples.

Statistics. All data are expressed as the mean \pm SEM and were analyzed nonparametrically using the Wilcoxon matched-paired signedrank test for paired data, and the Spearman rank-order correlation test.

\section{Results}

Characteristics of the patients are shown in Table I. Before detraining, body mass index was $23.3 \pm 0.4 \mathrm{~kg} / \mathrm{m}^{2}$, and body fat content was $18.3 \pm 1.3 \%(n=5)$. After $14 \mathrm{~d}$ of detraining, there were no significant changes in body mass index $(23.4 \pm 0.4 \mathrm{~kg} /$ $\mathrm{m}^{2}$ ) or percent fat content $(17.9 \pm 1.6 \%)$. In addition, there were no significant changes in cholesterol (from $171 \pm 8.3$ to $179 \pm 8.1 \mathrm{mg} / 100 \mathrm{ml}$ ), HDL cholesterol (from $58 \pm 3.2$ to $58 \pm 3.3 \mathrm{mg} / 100 \mathrm{ml}$ ), or triglycerides levels (from $79 \pm 7.4$ to $83 \pm 15 \mathrm{mg} / 100 \mathrm{ml}$ ). Fasting serum insulin levels increased slightly, but significantly, after detraining, from $11.3 \pm 0.9$ to 14.1 $\pm 1.3 \mu \mathrm{U} / \mathrm{ml}(P<0.05)$.

In muscle, detraining resulted in a significant decrease in both HR and EXT LPL activity, although the changes were greater in the EXT fraction (Fig. $1 A$ ). In the trained subjects HR LPL activity decreased $45 \%$, from $1.13 \pm 0.22$ to $0.62 \pm 0.16$ nEq FFA released / min per gram after detraining $(P<0.05)$; EXT LPL activity decreased $75 \%$ from $12.0 \pm 3.68$ to $2.77 \pm 1.09$ nEq FFA/min per gram $(P<0.005)$. When LPL immunoreactive mass was measured, detraining resulted in no significant change (Fig. $1 B$ ), either in the HR fraction (from $10.80 \pm 2.63$ to $14.11 \pm 5.04 \mathrm{ng} / \mathrm{g}$ ) or EXT fraction (from $120.49 \pm 21.56$ to $114.83 \pm 25.58 \mathrm{ng} / \mathrm{g}$ ).

RNA was extracted and Northern blots were performed in
14 subjects, and representative Northern blots are shown in Fig. $2 A$. Overall, there was no significant change in LPL mRNA levels, when expressed in relation to either total RNA or gamma-actin. In the two representative subjects shown in Fig. $2 A$, there were no changes in LPL mRNA or LPL mass, in spite of a decrease in LPL activity. The autoradiographic bands of the Northern blots were quantitated by laser densitometry, and Fig. $2 B$ shows no change in LPL/gamma-actin ratio after detraining.

Although there was no change in mean LPL mass or mRNA levels in muscle with detraining, several subjects demonstrated parallel decreases in LPL activity, LPL mass, and LPL mRNA levels. This is illustrated with the two subjects shown in Fig. 3. The subjects who demonstrated these changes were not different from the other subjects in any identifiable way. When LPL mass and mRNA levels were examined in all subjects, LPL mass appeared to be determined in part by the changes in mRNA levels. As shown in Fig. 4, there was a significant correlation between the change in LPL mRNA level and the change in LPL mass $\left(r_{s}=0.690, P<0.02\right)$.

In adipose tissue, detraining had the opposite effect on LPL activity (Fig. $5 \mathrm{~A}$ ). In the HR fraction there was a significant increase in LPL activity after detraining (from $0.20 \pm 0.04$ to $0.38 \pm 0.07 \mathrm{nEq}$ FFA released $/ \mathrm{min}$ per $10^{6}$ cells, $\left.P<0.005\right)$. However, there was no change in LPL EXT activity (from $3.96 \pm 2.01$ to $3.16 \pm 0.76 \mathrm{nEq}$ FFA $/$ min per $10^{6}$ cells). These changes in activity were paralleled by LPL immunoreactive mass; thus, there was a significant increase in LPL HR mass (from $1.79 \pm 0.29$ to $3.62 \pm 0.96 \mathrm{ng} / 10^{6}$ cells, $P=0.02$ ), with no significant change in LPL EXT mass (from $22.28 \pm 3.49$ to $28.57 \pm 4.87 \mathrm{ng} / 10^{6}$ cells) (Fig. $5 \mathrm{~B}$ ).

To further examine the mechanism of LPL regulation in adipose tissue after detraining, $\left[{ }^{35} \mathrm{~S}\right]$ methionine pulse-labeling
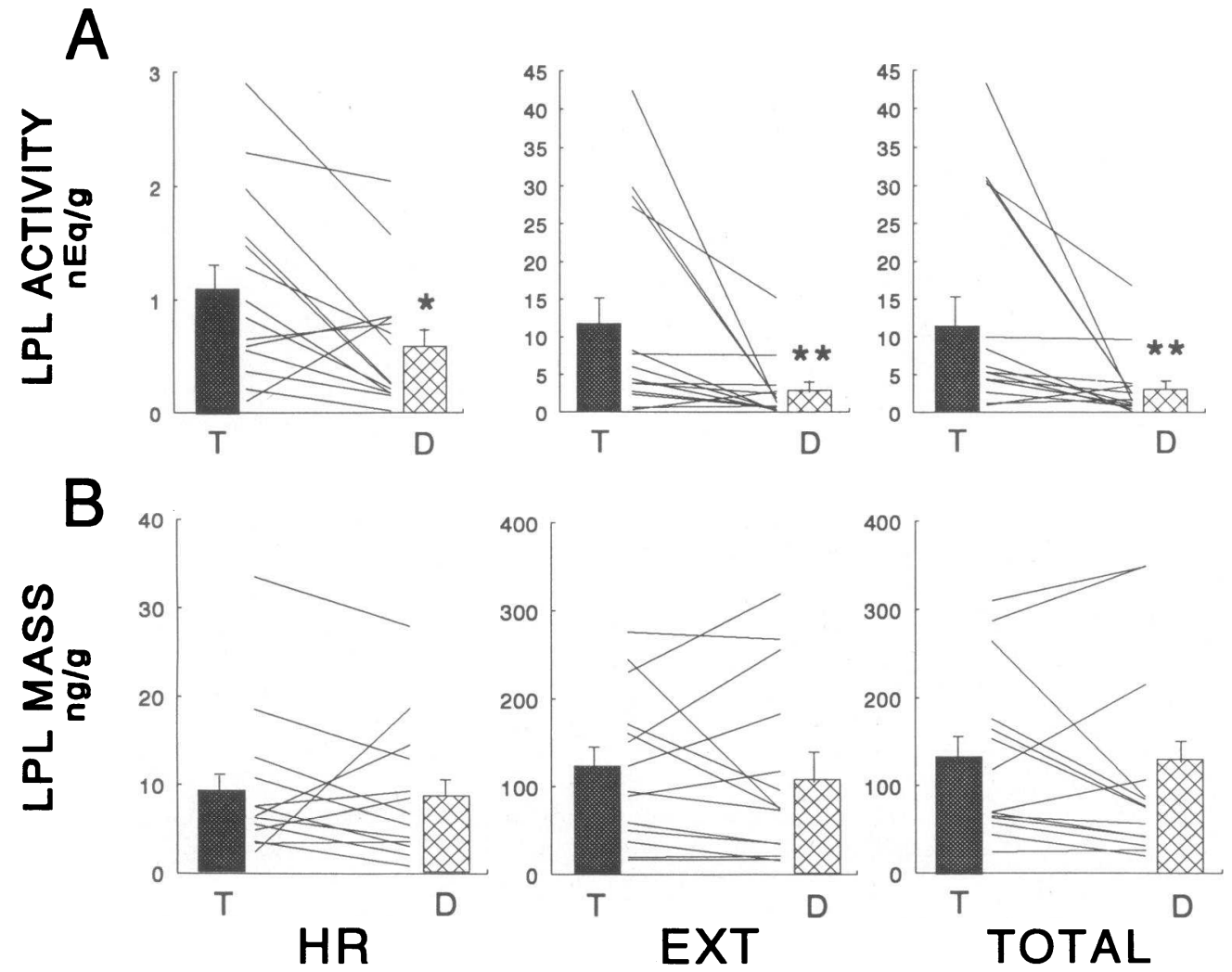

Figure 1. Muscle LPL activity and mass with detraining. LPL activity $(A)$ and LPL immunoreactive mass $(B)$ were measured in the HR and EXT compartments of adipose tissue. Results are shown as mean \pm SEM. ${ }^{*} P$ $<0.05 ;{ }^{* *} P<0.005 ; n=14$. 


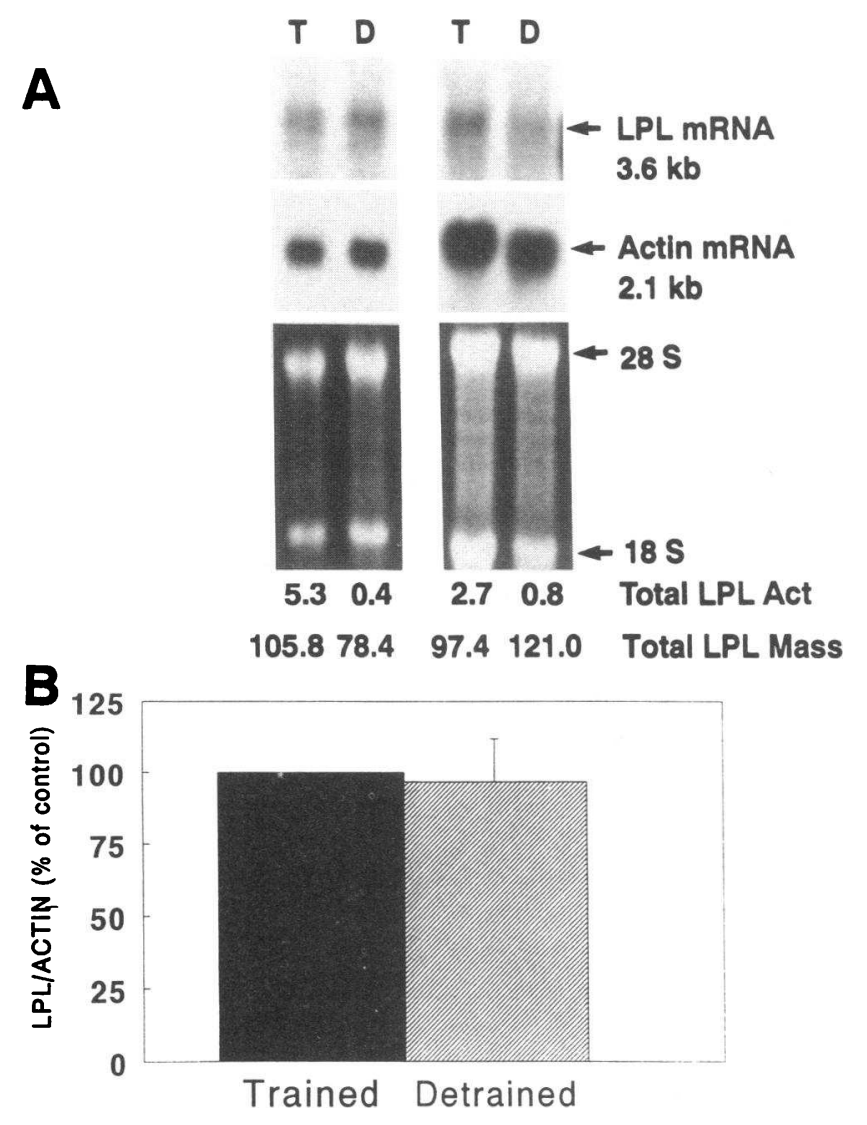

Figure 2. Muscle LPL mRNA levels with detraining. RNA was extracted from muscle both before and after detraining, and the extracted total RNA was analyzed by Northern blotting using the [ $\left.{ }^{32} \mathrm{P}\right]-$ cDNAs for LPL and gamma-actin. $(A)$ Northern blots of two representative runners. $(B)$ The images of the Northern blots of 14 subjects were quantitated using densitometry. The LPL/gamma-actin ratio is expressed as a percentage of the LPL/gamma-actin ratio from the first biopsy. $(T)$ trained; $(D)$ detrained $(n=14)$.

of adipose tissue was performed, along with mRNA extraction and Northern blotting. Fig. $6 \mathrm{~A}$ illustrates the data of two representative patients, showing no change in $\left[{ }^{35} \mathrm{~S}\right]$ methionine incorporation into LPL (top), along with no changes in LPL

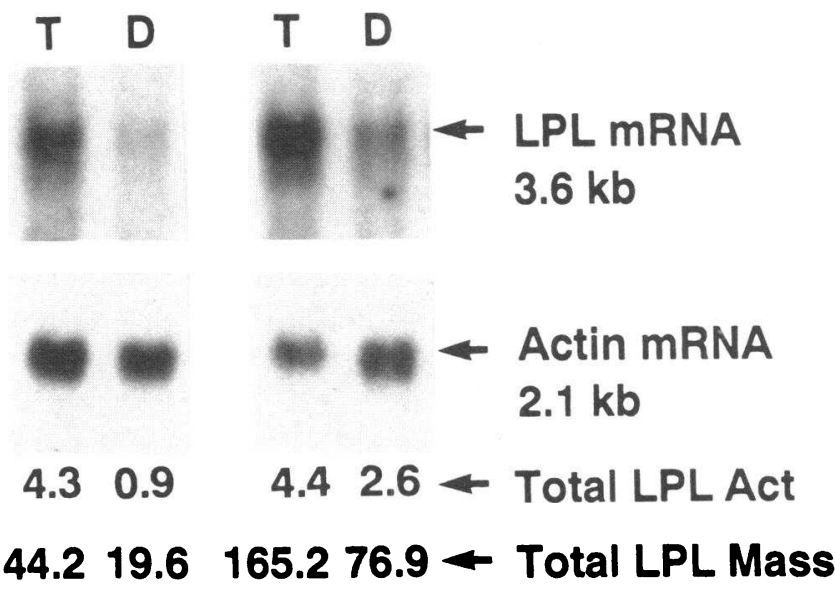

Figure 3. Muscle LPL mRNA levels in two subjects. Northern blots of two representative subjects are shown who demonstrated a decrease in muscle LPL mRNA levels. LPL activity and mass levels are shown for each subject.

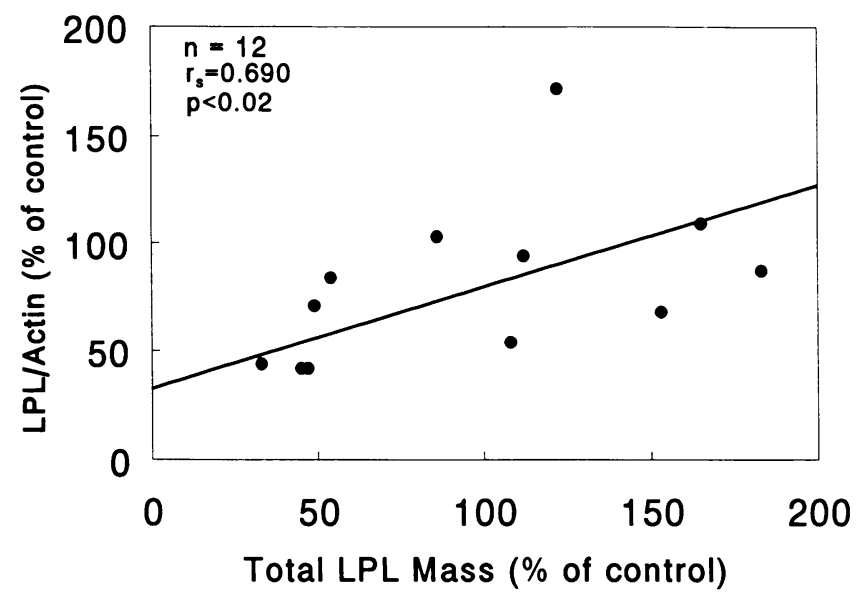

Figure 4. Relationship between muscle LPL mass and mRNA levels. The linear regression between the change in total LPL immunoreactive mass and the change in LPL/actin mRNA ratio is shown. The change is expressed as a percent of the value when "trained." The regression line is based on 12 subjects from whom there was complete data.

mRNA levels after detraining, when compared with gammaactin mRNA levels (middle and bottom). Fig. $6 \mathrm{~B}$ shows the LPL/actin mRNA ratio from adipose tissue, standardized to the LPL/actin ratio from the first biopsy.

Dietary lipid is catabolized by LPL, and therefore the relative proportion of LPL in muscle vs. adipose tissue should be important in determining whether lipid is stored in adipose tissue, or catabolized in muscle. Therefore, the adipose/muscle LPL activity ratio may be important as an index of the propensity for storage of the lipid in adipose tissue. A high ratio would favor diversion of lipid to adipose tissue for storage, whereas a low ratio would favor diversion of lipid to muscle for oxidation. When we examined this ratio in the runners, there was a signifcant increase in adipose / muscle LPL after detraining in all the LPL fractions (Fig. 7). The adipose/muscle total LPL ratio was $0.51 \pm 0.17$ in the trained runners, and increased to $4.45 \pm 2.46$ in the same runners after detraining $(P<0.05)$.

\section{Discussion}

LPL is present mainly in adipose tissue and muscle, and is a key enzyme in the uptake of FFA from plasma triglycerides. In human adipose tissue, little of the lipid found in the storage droplet is synthesized de novo, but instead is derived from FFA of hydrolyzed triglycerides $(2,21,22)$, therefore making LPL an important enzyme for lipid storage. In contrast, muscle uses FFA from circulating triglycerides for oxidation (3).

The effects of exercise training on LPL activities have been previously reported both in experimental animals and humans. In animals, the results have been inconsistent. Borensztajn et al. (23) found a significant increase of LPL activity with exercise in tissue homogenates of all fiber types of skeletal muscle. In contrast, other investigators were unable to find any difference in LPL activity of either muscle or adipose tissue between trained and sedentary rats (24-26). Oscai et al. (27) found a significant increase of the intracellular fraction of muscle LPL, with no change of the HR fraction during strenuous exercise in rats. On the other hand, in obese Zucker rats, training produced an increase in HR in both muscle and adipose tissue (28). 

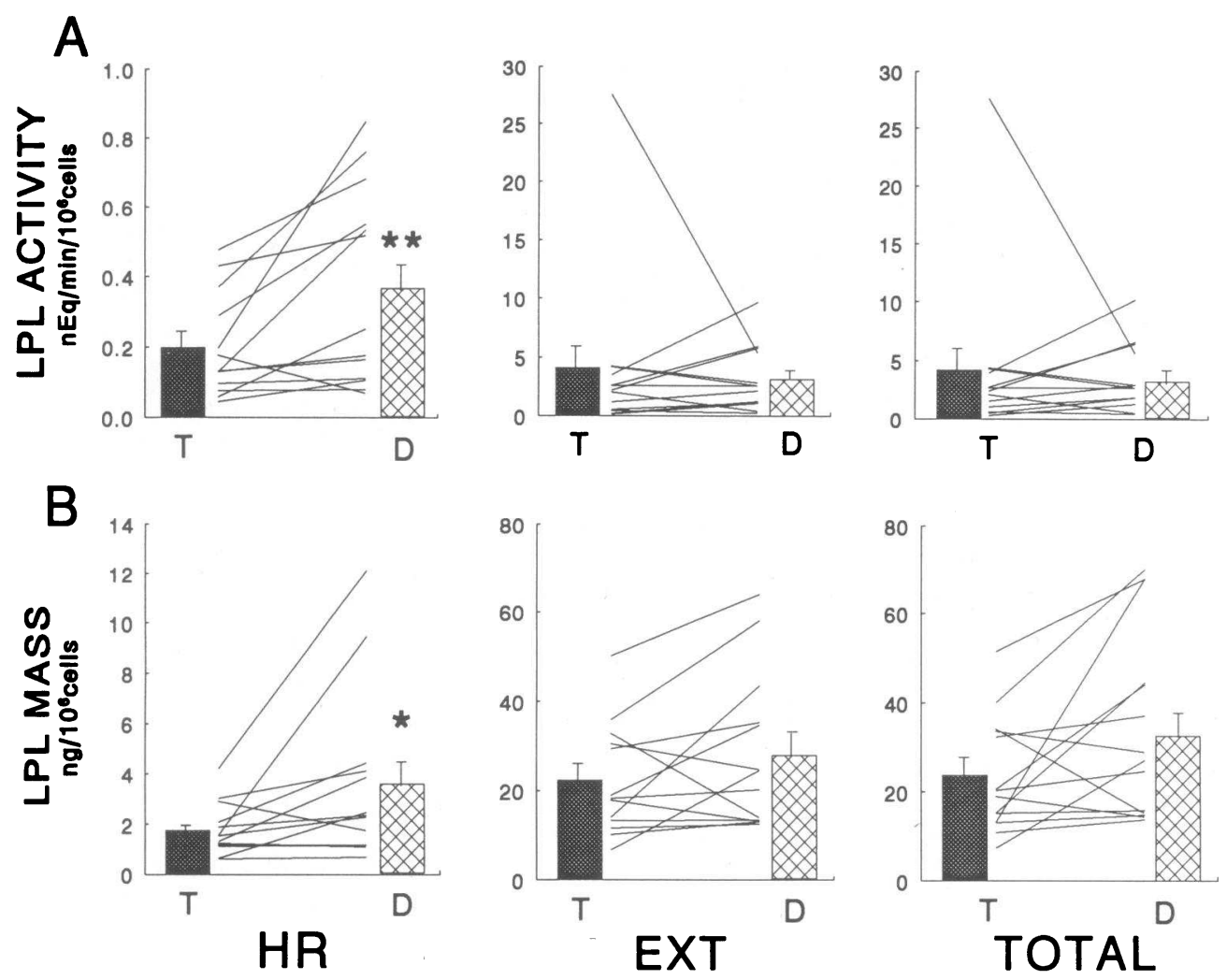

Figure 5. Adipose tissue LPL activity and mass with detraining. LPL activity $(A)$ and LPL immunoreactive mass $(B)$ were measured in the HR and EXT compartments of muscle tissue. Results are expressed as mean \pm SEM. ${ }^{*} P=0.02 ;{ }^{* *} P$ $<0.005 ; n=13$.

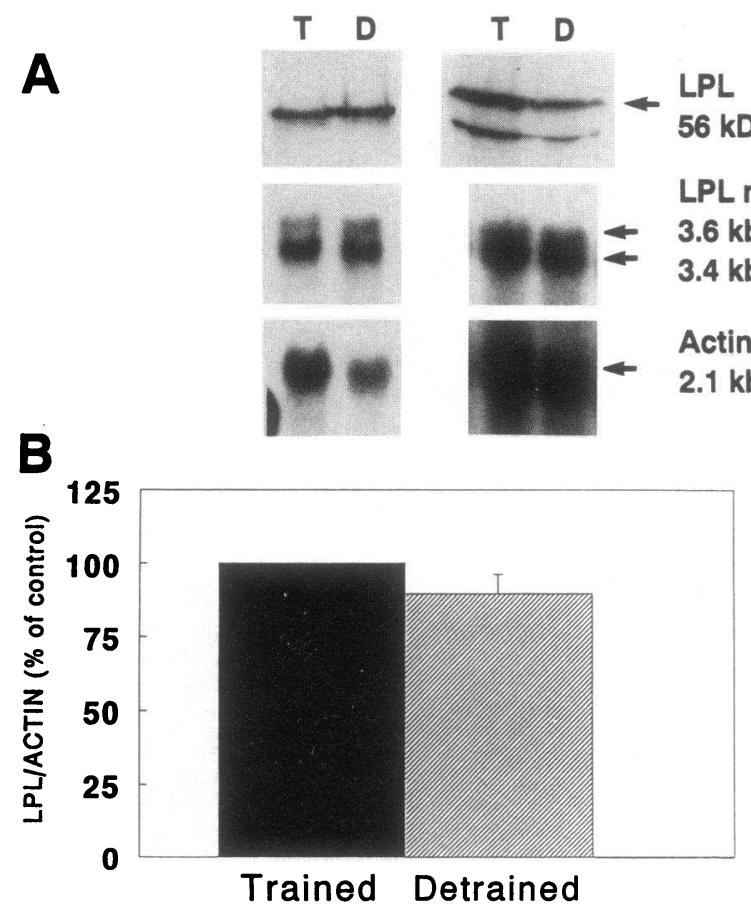

Figure 6. Adipose tissue LPL synthetic rate and mRNA levels with detraining. $(A)$ Adipose tissue LPL was pulse labeled with $\left[{ }^{35} \mathrm{~S}\right]-$ methionine for $30 \mathrm{~min}$, followed by immunoprecipitation and SDSPAGE (top). The lower band in the right-hand panel is nonspecific (does not compete with unlabeled LPL). RNA was extracted from the adipose tissue both before and after detraining, and the extracted total RNA was analyzed by Northern blotting using the $\left[{ }^{32} \mathrm{P}\right] \mathrm{cDNAs}$ for LPL and gamma-actin (middle). (B) The images from the Northern blots of 10 patients were quantitated using densitometry. The LPL/gamma-actin ratios were expressed as a percentage of the LPL/gamma-actin ratio during the trained period. $(T)$ trained; $(D)$ detrained $(n=10)$.

Studies in human subjects have consistently shown significant increases in LPL activity with exercise (reviewed in reference 4). Most studies have observed increases in postheparin plasma LPL activity (29-32), and others have noted increases in the HR fraction in both skeletal muscle and adipose tissue with endurance training (4). The HR fraction predominantly represents the fraction bound to the endothelium, and in adipose tissue is the fraction most subject to regulation. In muscle, trained subjects demonstrate a 30-70\% increase in LPL activity. In addition, a combination of regular training and acute exercise further increased muscle LPL activity; posttraining levels of LPL activity may reach up to 10-fold basal levels (33-35).

The mechanism of regulation of LPL is complex, and previous studies have noted changes in LPL at the level of LPL mRNA $(5,15,36-41)$, LPL translation (16, 42-45), and LPL posttranslational processing $(8,42,43,46,47)$. Previous studies have not examined the mechanism of regulation of LPL by exercise, so we attempted to determine whether the changes in LPL activity observed in trained subjects were due to an increase in LPL mRNA levels, or secondary to posttranslational effects.

In this study, we recruited well-trained subjects and measured adipose tissue and muscle LPL before and after 10-14 d of detraining. Due to the short time period between the biopsies, we were able to avoid changes in weight that could confound the effects of detraining on LPL. In muscle, detraining led to a significant decrease in LPL activity in both HR and EXT, although the greatest changes were observed in the EXT fraction. It should be noted that most of the LPL in muscle is found in the extractable fraction (48), which is opposite to adipose tissue, where most activity is in the HR fraction. In most subjects, however, this decrease in muscle LPL was not accompanied by a decrease in LPL immunoreactive mass. In addition, there were no overall changes in LPL mRNA levels in 


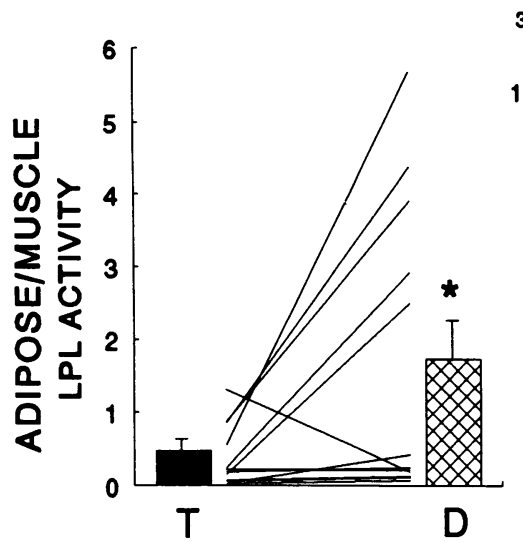

HR

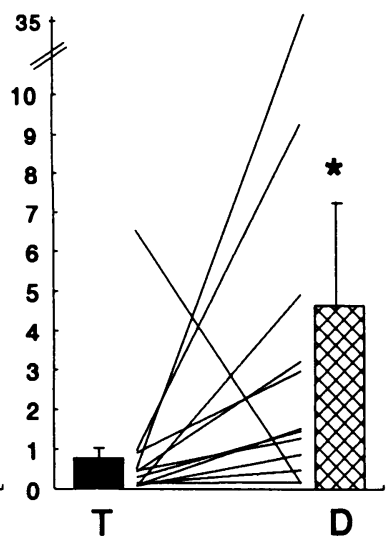

EXT

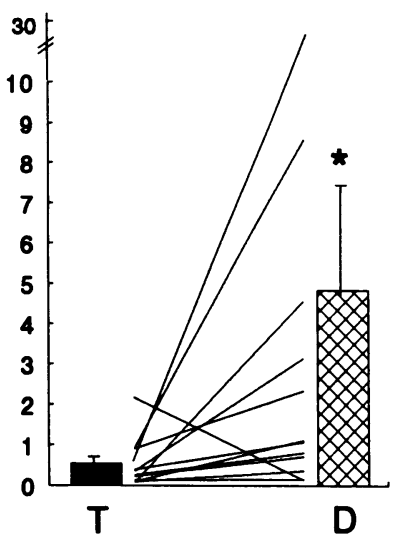

TOTAL
Figure 7. Effect of exercise detraining on adipose tissue/muscle LPL ratio. This ratio is shown for total LPL, as well as for the HR and EXT fractions. ${ }^{*} P$ $<0.05(n=12)$. muscle when compared to gamma-actin mRNA levels. However, although the group as a whole showed no changes in mass and mRNA levels, several subjects demonstrated important decreases in both parameters. Thus, the decrease in muscle LPL activity without changes in LPL mass and LPL mRNA levels suggests a posttranslational regulation of muscle LPL by exercise. However, there may be some variability among different human subjects, with some individuals regulating LPL in muscle either through changes in transcription or mRNA stabilization. The change in LPL mRNA levels, when it occurred, was directly proportional to muscle EXT LPL mass, suggesting that this large pool of mostly inactive LPL reflects the translation of muscle LPL mRNA.

In adipose tissue, detraining had the opposite effects on LPL, leading to a significant increase in HR activity that was paralleled by a significant increase in HR mass. No change in EXT activity or mass was detected, and additional experiments found no change in adipose LPL synthetic rate (using $\left[{ }^{35} \mathrm{~S}\right]-$ methionine labeling) or LPL mRNA levels (using Northern blotting). Therefore, the increase in adipose tissue LPL activity with detraining was also posttranscriptional. However, the selective increase in HR activity and mass suggests that exercise detraining specifically leads to an increase in adipose tissue LPL secretion, or LPL accumulation on the capillary endothelium. As described above, other studies have observed increases in LPL after exercise. Although the reason for the differences between this and other studies is not clear, other studies have not examined adipose tissue LPL in human subjects using a detraining protocol, as described herein. Studies that use long-term training may affect LPL in adipose tissue differently than short-term detraining, perhaps due to changes in adipocyte size associated with loss of fat mass. Such changes may alter LPL in a manner analogous to weight loss $(5,49)$. This study did not attempt to examine the effects of acute exercise. Since the first set of studies were performed $24 \mathrm{~h}$ after the last bout of exercise, the subjects had predominantly recovered from the exercise, but were still reaping the metabolic benefits. The subjects were likely at their peak of insulin sensitivity at the time of the first biopsy, and significantly less insulin sensitive after detraining $(50,51)$.

The regulation of LPL in adipose tissue and muscle has important implications for the disposal of lipoprotein-triglyceride. Because of the ability of LPL to divert triglyceride-lipid either to storage in fat or to oxidation in muscle, conditions that tend to increase adipose LPL or decrease muscle LPL would be expected to result in a shunting of circulating lipid towards storage in adipose tissue, and hence favor the development of obesity. Although this study did not examine obese subjects, exercise is widely held to be essential for weight maintenance after weight loss. In addition to the beneficial effects of exercise on energy consumption, this study would suggest that exercise also decreases the adipose/muscle LPL ratio, which would tend to prevent adipose lipid accumulation by partitioning more lipoprotein lipid into muscle for oxidation.

In summary, exercise detraining in athletes resulted in an increase in adipose tissue LPL and a decrease in muscle LPL, and both of these changes occurred posttranslationally, even though a transcriptional regulation may also occur in muscle in some subjects. In these athletes, detraining resulted in changes in LPL in adipose tissue and muscle that would be expected to favor the development of increased adiposity.

\section{Acknowledgments}

We thank Dr. Frank Shellock for performing the measurements of body composition, and Robert Karjala for the measurements of blood insulin levels. We thank Mehrnoosh Ghiam and Mimi Silver for their technical assistance.

\section{References}

1. Eckel, R. H. 1989. Lipoprotein lipase: a multifunctional enzyme relevant to common metabolic diseases. N. Engl. J. Med. 320:1060-1068.

2. Eckel, R. H. 1987. Adipose tissue lipoprotein lipase. In Lipoprotein Lipase. J. Borensztajn, editor. Evener Publishers, Chicago. 79-132.

3. Cryer, A. 1987. Comparative biochemistry and physiology of lipoprotein lipase. In Lipoprotein Lipase. J. Borensztajn, editor. Evener, Chicago. 277-327.

4. Nikkilä, E. A. 1987. Role of lipoprotein lipase in metabolic adaptation to exercise and training. In Lipoprotein Lipase. J. Borensztajn, editor. Evener, Chicago. 187-199.

5. Kern, P. A., J. M. Ong, B. Saffari, and J. Carty. 1990. The effects of weight loss on the activity and expression of adipose-tissue lipoprotein lipase in very obese humans. N. Engl. J. Med. 322:1053-1059.

6. Kiens, B., H. Lithell, K. J. Mikines, and E. A. Richter. 1989. Effects of insulin and exercise on muscle lipoprotein lipase activity in man and its relation to insulin action. J. Clin. Invest. 84:1124-1129.

7. Kern, P. A. 1991. Lipoprotein lipase and hepatic lipase. Curr. Opin. Lipidology. 2:162-169.

8. Ong, J. M., and P. A. Kern. 1989. Effect of feeding and obesity on lipoprotein lipase activity, immunoreactive protein, and messenger RNA levels in human adipose tissue. J. Clin. Invest. 84:305-311.

9. Lukaski, H. C., W. W. Bolonchuk, C. B. Hall, and W. A. Siders. 1986. Validation of tetrapolar bioelectrical impedance method to assess human body composition. J. Appl. Physiol. 60:1327-1332. 
10. Segal, K. R., B. Gutin, E. Presta, J. Wang, and T. B. Van Itallie. 1985. Estimation of human body composition by electrical impedance methods: a comparative study. J. Appl. Physiol. 58:1565-1571.

11. Kern, P. A., J. M. Ong, J. F. Goers, and M. E. Pedersen. 1988. Regulation of lipoprotein lipase immunoreactive mass in isolated human adipocytes. J. Clin. Invest. 81:398-406.

12. Nilsson-Ehle, P., and M. C. Schotz. 1976. A stable radioactive substrate emulsion for assay of lipoprotein lipase. J. Lipid Res. 17:536-541.

13. Belfrage, P., and M. Vaughn. 1969. Simple liquid-liquid partition system for isolation of labeled oleic acid from mixture with glycerides. J. Lipid Res 10:341-344.

14. Goers, J. F., M. E. Petersen, P. A. Kern, J. Ong, and M. C. Schotz. 1987 Enzyme-linked immunoassay for lipoprotein lipase. Anal. Biochem. 166:27-35

15. Ong, J. M., T. G. Kirchgessner, M. C. Schotz, and P. A. Kern. 1988. Insulin increases the synthetic rate and messenger RNA level of lipoprotein lipase in isolated rat adipocytes. J. Biol. Chem. 263:12933-12938.

16. Simsolo, R. B., J. M. Ong, B. Saffari, and P. A. Kern. 1992. Effect of improved diabetes control on the expression of lipoprotein lipase in human adipose tissue. J. Lipid Res. 33:89-95.

17. Chomczynski, P., and N. Sacchi. 1987. Single-step method of RNA isolation by acid guanidinium thiocyanate-phenol-chloroform extraction. Anal. Biochem. 162:156-159.

18. Feinberg, A. P., and B. Vogelstein. 1983. A technique for radiolabeling DNA restriction endonuclease fragments to high specific activity. Anal. Biochem. 132:6-13.

19. Wion, K. L., T. G. Kirchgessner, A. J. Lusis, M. C. Schotz, and R. M. Lawn. 1987. Human lipoprotein lipase complementary DNA sequence. Science (Wash. DC). 235:1638-1641.

20. Gunning, P., P. Ponte, H. Okayama, J. Engel, H. Blau, and L. Kedes. 1983. Isolation and characterization of full-length cDNA clones for human a-, B-, and g-actin mRNA's: skeletal but not cytoplasmic actin have an amino-termina cysteine that is subsequently removed. Mol. Cell. Biol. 3:787-798.

21. Hollenberg, C. H. 1966. The origin and glyceride distribution of fatty acids in rat adipose tissue. J. Clin. Invest. 45:205-216.

22. Shrago, E., T. Spennetta, and E. Gordon. 1969. Fatty acid synthesis in human adipose tissue. J. Biol. Chem. 244:2761-2766.

23. Borensztajn, J., M. S. Rone, S. P. Babirak, J. A. McGarr, and L. B. Oscai 1975. Effect of exercise on lipoprotein lipase activity in rat heart and skeleta muscle. Am. J. Physiol. 229:394-397.

24. Ch'ng, J. L., R. C. Mulligan, P. Schimmel, and E. W. Holmes. 1989 Antisense RNA complementary to $3^{\prime}$ coding and noncoding sequences of creatine kinase is a potent inhibitor of translation in vivo. Proc. Natl. Acad. Sci. USA. 86:10006-10010.

25. Kruys, V., M. Wathelket, P. Poupart, R. Contreras, W. Flers, J. Content, and G. Huez. 1987. The $3^{\prime}$ untranslated region of the human interferon mRNA has an inhibitory effect on translation. Proc. Natl. Acad. Sci. USA. 89:6030-6034.

26. Walden, W. E., M. M. Patino, and L. Gaffield. 1989. Purification of a specific repressor of ferritin mRNA translation from rabbit liver. J. Biol. Chem 264:13765-13769.

27. Oscai, L. B., R. A. Caruso, and A. C. Wergeles. 1982. Lipoprotein lipase hydrolyzes endogenous triacylglycerols in muscle of exercised rats. J. Appl. Physiol. 52:1059-1063.

28. Walberg, J. L., M. R. C. Greenwood, and J. Stern. 1983. Lipoprotein lipase activity and lipolysis after swim training in obese Zucker rats. Am. J. Physiol. 425:R706-R712.

29. Costill, D. L., P. Cleary, W. J. Fink, C. Foster, J. L. Ivy, and F. Witzmann 1979. Training adaptations in skeletal muscle of juvenile diabetics. Diabetes. 28:818-822.

30. Peltonen, P., J. Marniemi, E. Hietanen, I. Vuori, and C. Ehnholm. 1981. Changes in serum lipids, lipoproteins, and heparin releasable lipolytic enzymes during moderate physical training in man: a longitudinal study. Metabolismo. 30:518-525.
31. Svedenhag, J., H. Lithell, A. Juhlin-Dannfelt, and J. Henriksson. 1983. Increase in skeletal muscle lipoprotein lipase following endurance training in man. Atherosclerosis. 49:203-207.

32. Weintraub, M. S., Y. Rosen, R. Otto, S. Eisenberg, and J. L. Breslow. 1989. Physical exercise conditioning in the absence of weight loss reduces fasting and postprandial triglyceride-rich lipoprotein levels. Circulation. 79:1007-1014.

33. Taskinen, M. R., and E. A. Nikkila. 1980. Effect of acute vigorous exercise on lipoprotein lipase activity of adipose tissue and skeletal muscle in physically active men. Artery. 6:471-483.

34. Lithell, H., R. Schele, and B. Vessby. 1984. Lipoproteins, lipoprotein lipase and glycogen after prolonged physical activity. J. Appl. Physiol. 57:698702 .

35. Lithell, H., M. Cedermark, and J. Froberg. 1981. Increase of lipoprotein lipase activity in skeletal muscle during heavy exercise, relation to epinephrine excretion. Metabolismo. 30:1130-1134.

36. Querfeld, U., J. M. Ong, J. Prehn, J. Carty, B. Saffari, S. C. Jordan, and P. A. Kern. 1990. Effects of cytokines on the production of lipoprotein lipase in cultured human macrophages. J. Lipid Res. 31:1379-1386.

37. Ong, J. M., R. B. Simsolo, B. Saffari, and P. A. Kern. 1992. The regulation of lipoprotein lipase gene expression by dexamethasone in isolated rat adipocytes. Endocrinology. 130:2310-2316.

38. Ong, J. M., R. B. Simsolo, and P. A. Kern. 1992. Multiple levels of lipoprotein lipase gene expression in muscle: type I and II fibers, and effects of hypothyroidism. Circulation. 86:607. (Abstr.)

39. Fried, S. K., and R. Zechner. 1989. Cachectin/tumor necrosis factor decreases human adipose tissue lipoprotein lipase mRNA levels, synthesis, and activity. J. Lipid Res. 30:1917-1923.

40. Friedman, G., M. Ben-Naim, O. Halimi, J. Etienne, O. Stein, and Y. Stein. 1991. The expression of lipoprotein lipase activity and mRNA in mesenchymal rat heart cell cultures is modulated by bFGF. Biochim. Biophys. Acta. 1082:27-32.

41. Previato, L., C. L. Parrott, S. Santamarina-Fojo, and H. B. Brewer, Jr. 1991. Transcriptional regulation of the human lipoprotein lipase gene in 3T3-L adipocytes. J. Biol. Chem. 266:18958-18963.

42. Ong, J. M., B. Saffari, R. B. Simsolo, and P. A. Kern. 1992. Epinephrine inhibits lipoprotein lipase gene expression in rat adipocytes through multiple steps in posttranscriptional processing. Mol. Endocrinol. 6:61-69.

43. Ong, J. M., and P. A. Kern. 1989. The role of glucose and glycosylation in the regulation of lipoprotein lipase synthesis and secretion in rat adipocytes. $J$. Biol. Chem. 264:3177-3182.

44. Saffari, B., J. M. Ong, and P. A. Kern. 1992. Regulation of adipose tissue lipoprotein lipase gene expression by thyroid hormone in rats. J. Lipid Res. 33:241-249.

45. Giralt, M., I. Martin, S. Vilaró, F. Villarroya, T. Mampel, R. Iglesias, and O. Viñas. 1990. Lipoprotein lipase mRNA expression in brown adipose tissue: translational and/or posttranslational events are involved in the modulation of enzyme activity. Biochim. Biophys. Acta. 1048:270-273.

46. Doolittle, M. H., O. Ben-Zeev, J. Elovson, D. Martin, and T. G. Kirchgessner. 1990. The response of lipoprotein lipase to feeding and fasting. Evidence for posttranslational regulation. J. Biol. Chem. 265:4570-4577.

47. Davis, R. C., O. Ben-Zeev, D. Martin, and M. H. Doolittle. 1990. Combined lipase deficiency in the mouse. Evidence of impaired lipase processing and secretion. J. Biol. Chem. 265:17960-17966.

48. Borensztajn, J. 1987. Heart and skeletal muscle lipoprotein lipase. In Lipoprotein Lipase. J. Borensztajn, editor. Evener Publishers, Chicago. 133-148.

49. Schwartz, R. S., and J. D. Brunzell. 1981. Increase of adipose tissue lipoprotein lipase activity with weight loss. J. Clin. Invest. 67:1425-1430.

50. Heath, G. W., Gavin, J. R. III, and J. M. Hinderliter. 1983. Effects of exercise and lack of exercise on glucose tolerance and insulin sensitivity. J. Appl. Physiol. 55:512-517.

51. Horton, E. S. 1986. Exercise and physical training: effects on insulin sensitivity and glucose metabolism. Diabetes Metab. Rev. 2:1-44. 